\title{
Social entrepreneurship as a factor of sustainable development in the context of «Crisis 2020» in Russian Federation
}

\author{
Kulkova Varvara $^{1 *}$, Galimova Alina ${ }^{1}$, Kursina Irina $^{2}$, and Matveeva Elena ${ }^{2}$ [0000-0002-1669-6415] \\ ${ }^{1}$ Kazan State Power Engineering University, 420066, Kazan, Krasnoselskaya st., Russia \\ ${ }^{2}$ Kazan State University of Architecture and Engineering, 420043, Zelenaya st., Kazan, Russia
}

\begin{abstract}
Social entrepreneurship is considered to be an emergent, independent form of social responsible business implementation. «What is the state of social entrepreneurship during «Crisis 2020», how does the digital evolution occur» are the burning questions that led to the relevance of the research topic and goal setting. The main purpose is to figure out the special features of social entrepreneurship's fostering as a virtuous tool to fulfil contemporary targets of sustainable growth in case of «Crisis 2020». Research methods: general scientific - induction and deduction, analysis and synthesis, generalization and comparison of the positioning of social entrepreneurship as a factor of economic growth in the modern paradigm of sustainable development; empirical research based on a questionnaire survey of social entrepreneurs. The positioning of social entrepreneurship as a factor of economic growth in the modern paradigm of sustainable development is scientifically substantiated based on the identification of practices in the cases of social entrepreneurship with the goals of sustainable development. The factors limiting development and the adaptive options of social entrepreneurship to the crisis conditions including online format acceptance that leads to uncovering fresh opportunities for working activities.
\end{abstract}

Keywords: social entrepreneurship, sustainable development, 2020 Crisis, digital evolution, economic growth, goals, concept.

\section{Introduction}

The entrepreneurship has happened to be the determinant factor of an economical growth since the days of Adam Smith. The new paradigm of economical growth is being formed in the current situation within the bounds of stable development concept that was elaborated by the UN. Amidst the «Crisis 2020» caused by WHO-declared COVID-19, pandemic, economic entities came across new challenges that pose risks to sustainability and survival. At the same time social consolidation in solving problems, that have arisen, has grown in the development of intersectional social partnership between government-business-nonprofit organizations-citizens. It is the factor that has given ample opportunities for business

* Corresponding author: kulkova77@mail.ru 
structures to implement social responsibilities synced with the achievement of stable progress. Social entrepreneurship is considered to be an emergent, independent form of social responsible business implementation. The necessity of social entrepreneurship's expansion is defined not only with a failure to resolve severe economical and social issues, but also with the search for a qualitatively new, innovative solution that are aimed for successful reforms in the constituent entities of Russian Federation. Thus, the governmental support at the regional level contributes to the business' growth. «Crisis 2020» conditions brought about by the need for an anti-crisis policymaking (initiated by the Government of Russian Federation). It had small, medium enterprises and non- commercial organizations delineated to an independent category.

«What is the state of social entrepreneurship during «Crisis 2020», how does the digital evolution occur» are the burning questions that led to the relevance of the re-search topic and goal setting. The main purpose is to figure out the special features of social entrepreneurship's fostering as a virtuous tool to fulfill contemporary targets of sustainable growth in case of «Crisis 2020».

The significance of research results consists in scientific grounding of social entrepreneurship positioning as a factor of sustainable development in the context of «Crisis 2020».

The results' novelty comprises in revealing facts and perspectives of social entrepreneurship's stable advancement throughout «Crisis 2020», which are based on consolidation of received expert assessment engaged in this form of business sector. These entrepreneurs emphasize the adaptive options of social entrepreneurship to the crisis conditions including online format acceptance that leads to uncovering fresh opportunities for working activities.

\section{Materials and methods}

\subsection{Brief Literature Review}

The steady growth concept has endured extended evolution and mutated in accordance with new global agendas. It is known to allocate the next core scientific ways: ecologicalsystematic approach established by V. I. Vernadsky [1], economical approach to stable development considered as an achieving equilibrium state of supply and demand (in domestic science developed by G. V.Semenov [2]), till the concept of social follow-up by H. Daly and R. Costanza [3], corporative sustainability by J. Elkington [4]. On the whole, the results of synthesizing conceptual approaches to the sustainable development and separate practices of entrepreneurial structures are presented amongst domestic researches [5-6]. The modern paradigm of stable development was elaborated in New York back to 2015. It includes the mode of doing business based on the need for balance between solving social, economical issues and preserving ecology, natural resources. Nowadays, concepts and goals of stable development (hereinafter referred to as GoSD) are followed with global problem, which is COVID-19 pandemic that has triggered «Crisis 2020».

Social entrepreneurship is the modern form of business' social responsibility realization synced with the achievement of sustainable development goals, since that kind of entrepreneurship is now focused on life improvements among social unsafe segments of population, development of local communities and ecological projects, overcoming poverty, environmental preservation. The consolidation of socially oriented NPOs (hereinafter referred to as SO NPOs) and social entrepreneurship into a group of non-state providers of social services is getting grounding in scientific schools within the confines of «earned income» concept by Boschee J., McClurg [7], «hybrid organizations» Alter S. K 
[8]. At the same time there is a number of scientists A. A. Moskovskaya, M. Batalina, L. Taradina [9], Dennis Rich [10], differentiating these concepts. NPOs as an organizational and legal form has been removed from Russian legislation since 2019. According to the Federal law, the concept «social entrepreneurship» is disclosed in paragraph 7 of Art 3 No. 245 -Federal Law, and it is considered as «an entrepreneurial activity aimed at achieving socially useful goals, contributing to the solution of social problems of citizens and society and carried out in accordance with the conditions provided for in Part 1 of Article 24.1 of this Federal Law» [11].

The digital transformation, which involves working processes of social enterprises, speaks as one of modern trends aimed at marshalling stable development and getting speedactivation for growth in context of «Crisis 2020» [12].

The digitalization is meant to be the implementation of digital technologies into all spheres of national economy linking to studying scientific publications, commencing with researches of informational and network-based community by A.Toffler [13], Ch. Freeman [14], M.Castells [15] and ending with an approach used in practice [16]. Not only does the digital transformation imply the use of new digital technologies (Internet tools, (IoT), robotics, artificial intellect, big data), but also deep and complex transformation of products and services, organizational structure and development strategy of the organization, organizational culture, interactions with stakeholders (suppliers, partners and customers).

M. Castells and J. Habermas [17] also distinguish a negative side of informational technologies usage. At the days of informational technologies and digital evolution an intense flood of information occurs, which shapes the humans' dependence on information supplied, impossibility to distinguish truth from fake, the raise of the question about the existence of established standards of collaborations and interpersonal communications, conditioning an insecurity of personal data in the web.

Thus, based on the above issues and literature review, the inference is the following: social enterprises effectively implement the goals of sustainable development; the context of «Crisis 2020» set up the activation of digital technologies that is happen to be the modern trend of stable development.

\subsection{Methods}

The choice of the forward methods for research were defined by the goal set previously and the taken directions for sustainable development of social entrepreneurship.

Firstly, the method of generalization and comparison of the positioning of social entrepreneurship as a factor of economic growth in the modern paradigm of sustainable development. We have tested the compliance of sustainable development goals to the cases' content of social entrepreneurship taken from the catalog of the Fund of Regional Social Programs «Our Future» [18]. It is noteworthy, the goals distinguished for research are those that are most fully reflected in the practice of Russian social entrepreneurship.

Secondly, to overcome informational limits, we have gathered information through sociological survey by asking social entrepreneurs to figure out the state social entrepreneurship and digital evolution in the context of «Crisis 2020». The sample was formed at random. It includes social Russian entrepreneurs, who study at a seminar remotely, which is due to the availability of the expert base of the study. A survey was made on the perception of the crisis and digitalization, to which social entrepreneurs responded online. 


\section{Results and discussion}

The positioning of social entrepreneurship as a factor of economic growth in the modern paradigm of sustainable development is presented in Table 1.

Table 1. Social entrepreneurship (SE) and goals of development in the cases of Russian enterprises.

\begin{tabular}{|c|c|c|}
\hline $\begin{array}{c}\text { Goal of stable } \\
\text { development }\end{array}$ & Business model SE & Enterprises' case \\
\hline $\begin{array}{l}\text { Goal No. 1: Poverty } \\
\text { eradication } \\
\text { Goal No. 8: Decent } \\
\text { job and economical } \\
\text { growth } \\
\text { Goal No. 10: Reduce } \\
\text { of inequality } \\
\text { Goal No. 11: } \\
\text { Sustainable cities and } \\
\text { towns }\end{array}$ & $\begin{array}{l}\text { 1. Employment of socially } \\
\text { unprotected groups. } \\
\text { 2. Selling goods or services } \\
\text { to a socially vulnerable } \\
\text { group at an affordable price } \\
\text { 3. Development of the } \\
\text { territory around the product }\end{array}$ & $\begin{array}{l}\text { Cocco Bello cream honey } \\
\text { production. Guzel Sanzhapova } \\
\text { has employed the residents of } \\
\text { Maly Turysh and nearby villages, } \\
\text { began to design a Community } \\
\text { Center where people could spend } \\
\text { their free time, study, and receive } \\
\text { first aid for } 6 \text { years of the } \\
\text { production existence }\end{array}$ \\
\hline $\begin{array}{l}\text { Goal No. } 6 \text { : Clean } \\
\text { water and sanitation }\end{array}$ & $\begin{array}{l}\text { 1. Development of the } \\
\text { territory around the product }\end{array}$ & $\begin{array}{l}\text { Eco-ship «Trofim Yaskin» is a } \\
\text { patrol ship for ecological } \\
\text { monitoring of Lake Baikal. The } \\
\text { enterprise is engaged in cleaning } \\
\text { Lake Baikal from pollution on the } \\
\text { foundation of a innovative type of } \\
\text { resources, advantageous for the } \\
\text { region's development, as well as } \\
\text { the creation of environmentally } \\
\text { friendly devices, tourist activities } \\
\text { on the ship }\end{array}$ \\
\hline $\begin{array}{l}\text { Goal No.7: } \\
\text { Inexpensive and clean } \\
\text { energy }\end{array}$ & $\begin{array}{l}\text { 1. Usage and waste } \\
\text { treatment }\end{array}$ & $\begin{array}{l}\text { ECOPAD is a project in the } \\
\text { Moscow region aimed at the } \\
\text { production of eco-products from } \\
\text { scraps of the «life activity» of } \\
\text { printing enterprises. It is done by } \\
\text { creating notebooks and other } \\
\text { stationery by the forces of people } \\
\text { who find themselves in difficult } \\
\text { life situations and volunteers }\end{array}$ \\
\hline $\begin{array}{l}\text { Goal No. 12: } \\
\text { Responsible } \\
\text { consumption and } \\
\text { production }\end{array}$ & 1. Reuse and reuse resources & $\begin{array}{l}\text { «Vtornik». A charity store in the } \\
\text { Irkutsk region is engaged in the } \\
\text { conservation and reuse of } \\
\text { resources by collecting things that } \\
\text { have become unnecessary for the } \\
\text { locals, mainly clothes, then } \\
\text { sorting them, selling or resale for } \\
\text { charity }\end{array}$ \\
\hline
\end{tabular}

Social entrepreneurs are engaged in solving social issues, elaborating social innovations and introducing business solutions to make our world a better place. They develop innovative ideas, find necessary resources and solve social, ecological problems, thereby becoming the factor of sustainable development. 
The analysis outcome showed that majority of social entrepreneurs did not undergo any changes in work efficiency during the «Crisis 2020», however 26 per cent of experts state the reduction of productivity (Fig. 1).

How have the pandemic and online practices changed the way your organization works?

- Pandemic did not affect The result of the work has decreased

- Work efficiency has increased

$$
26 \%
$$

Fig 1. The question and respondents' answers.

Apparently, social entrepreneurs came across the lack of funding to pay wages, tax liabilities, and rental payments. The government initiated an anti-crisis policy that implements measures to preserve jobs, change the procedure for paying VAT, abolish taxes for small businesses, measures on lending conditions (a ban on requirements for early repayment of loans and a deferral of loan repayment for a year) to mitigate these problems.

The obtained expert assessments show that digitalization has increased amidst «Crisis 2020» (Fig. 2).

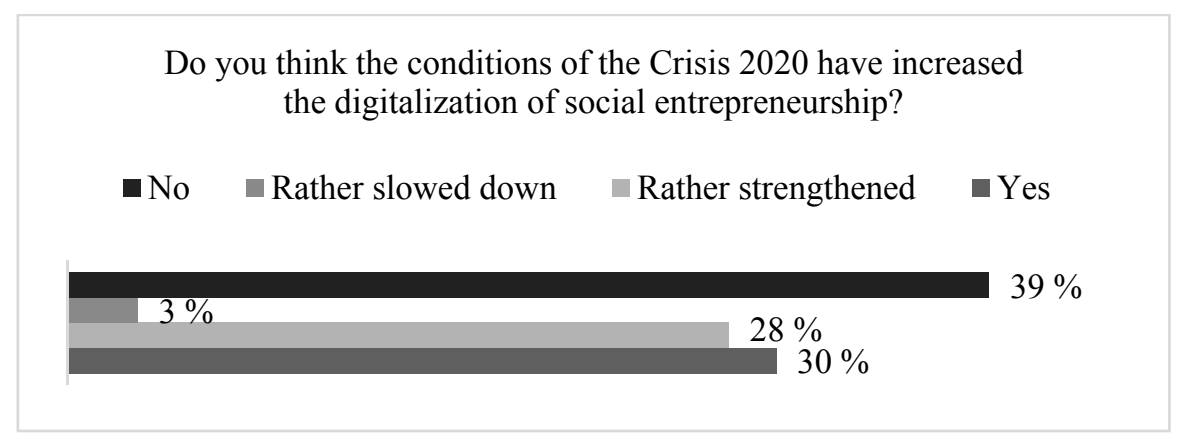

Fig. 2. The question and respondents' answers.

The context of «Crisis 2020» revealed perspectives for the growth on a new webmarketplace for entrepreneurs. By the time, most enterprises already had their own websites or informational Internet platforms, where they sold their goods and services, also advertised their activities however, the pandemic showed the need to modernize databases, restart portals. The lack of digital literacy of a target audience, that social entrepreneurship had, became one of troublesome moments. There was a need to implement training and retraining work with new technologies using online formats. Therefore, expert assessments concerning online format as a new opportunity were not a surprise (Fig. 3). 


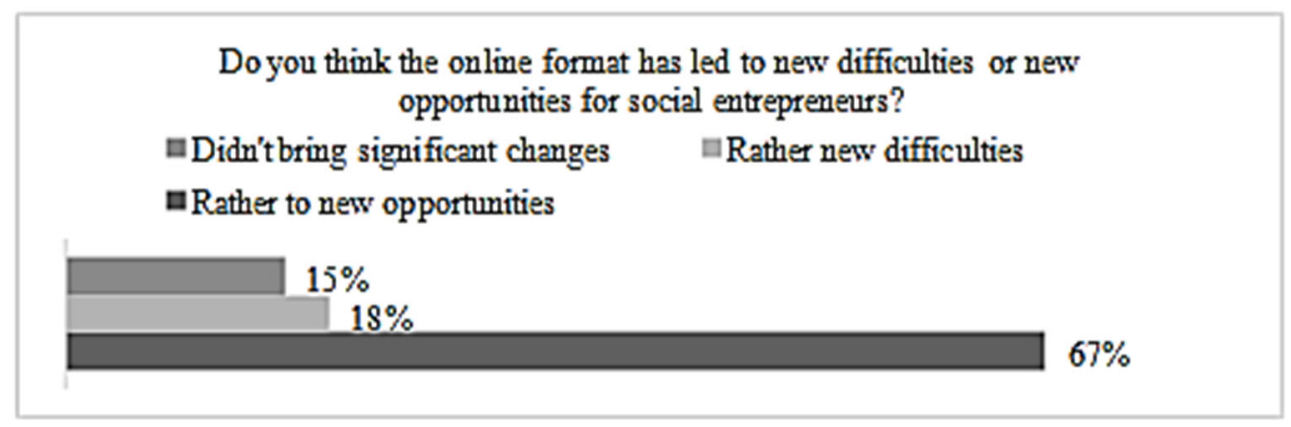

Fig. 3. The question and respondents' answers.

Business-processes have been optimized during the self-isolation period. It has affected even those processes that seem to be totally depended on personal contact of the company. For instance, the social enterprise for the production of hand prostheses «Motorika» adjusted its development plans by actively introducing models of remote work with patients and training production staff to work with technologies during the crisis. The enterprise also reduced costs to the limit: lease of office space, business trips, and control over the amount of inventories [19].

\section{Conclusions}

The research carried out within the confines of this goal provides the basis for the following generalizations, conclusions and recommendations.

Firstly, the pandemic, that triggered the Crisis 2020, increased the risks of achieving the SDGs, but also showed the need to develop socially oriented practices as «points of growth». We have proved that social entrepreneurship is a factor in achieving economic growth in the accepted modern concept of sustainable development, based on the identification of practices in the cases of social entrepreneurship with the goals of sustainable development.

Secondly, according to the results of the expert survey, the adaptive ability of social entrepreneurs to the conditions of the crisis was revealed, including diversification into network, digital technologies, the development of new directions and markets, as well as maintaining a stable position due to the state policy of supporting small and the introduction of digital transformation.

\section{References}

1. V. I. Vernadsky, Transactions on the general history of science (Science, 336,1988)

2. G. V. Semenov, National product: problems of deficit and balance: monograph (University Publishing House, Kazan, 158 (1993)

3. R. Costanza, H. E. Daly, Conservation Biology. Mar. Natural Capital and Sustainable Development, 1 (1992)

4. J. Elkington, Towards the Sustainable Corporation: Win-Win-Win, Business Strategies for Sustainable Development, California Management Review, 36 (1994) DOI: $10.2307 / 41165746$

5. V. Y. Kulkova, The implementation of internal corporate social responsibility of entrepreneurial structures in innovative HR management, Studies in Systems, Decision and 
Control, Complex Systems: Innovation and Sustainability in the Digital Age, 282, 1924 (2020) DOI: 10.1007/978-3-030-44703-8_3

6. O. V. Bakhareva, A. I. Romanova, R. S. Safina, I. M. Kursina, T. A. Shindina, Infrastructure in the region: long-term investments of institutional investors in Russia, Journal of Advanced Re-search in Law and Economics, 6, 3, 488-503 (2015) DOI: 10.14505/jarle.v6.3(13).04

7. J. Boschee, J. McClurg, Toward a better understanding of social entrepreneurship: some important distinctions (2003)

8. S. K. Alter, Social Enterprise Typology (Virtue Ventures LLC, 2007)

9. A. A. Moskovskaya, M. Batalina, L. Taradina, Review of the experience and concepts of social entrepreneurship, taking into account the possibilities of its application in modern Russia, 2, 84 (2008) URL: https://www.hse.ru/data/2010/05/04/1216403244/WP1_2008_02.pdf (last accessed: 18.03.2021)

10. J. Dennis Rich, The Importance of Mission for NGO's. URL: https://grans.hse.ru/mirror/pubs/sha re/306942079 (last accessed: 18.03.2021)

11. Federal Law of July 26, 2019 N 245-FZ «On Amendments to the Federal Law» On the Development of Small and Medium Business in the Russian Federation «in terms of consolidating the concepts of social entrepreneurship. URL: http://www.consultant.ru/document/cons_doc_LAW_329995 (last accessed: 20.03.2021)

12. A. Auzan, The economy during and after the pandemic: lecture. URL: https://www.econ.msu.ru/COVID-19/Auzan (last accessed: 20.03.2021)

13. E. Toffler, The third wave (ACT Publishing House, 2004)

14. C. Freeman, Changement technologique et economie mondiale, Dans Futuribles, 186, 25-50 (1994)

15. M. Castells, Information Age: Economy, Society and Culture (Blackwell, Oxford, 608, 2000)

16. An integrated approach to digital transformation of manufacturing enterprises, $\mathrm{PwC}$, Siemens PLM Software. 2017. URL:

https://www.PwC.ru/ru/publications/PwC_Siemens_Digital_transformation.pdf (last accessed 19.03.2021)

17. J. Habermas B. I-II. Frankfurt. Theorie des kommunikativen Handelns (1981)

18. Catalog of enterprises, goods and services of social entrepreneurs [Electronic resource]. URL: http://coindex.ru/page/contacts (last accessed: 19.03.2021)

19. Help to those who help: how social business in the Russian Federation has adapted to the conditions of the pandemic URL: https://tass.ru/msp/8573417 (last accessed: 19.03.2021) 